\title{
Identification of thermo tolerant lactic acid bacteria isolated from silage prepared in the hot and humid climate of Southwestern Japan
}

\author{
Katsumi Doi ${ }^{1 *}$, Yousuke Nishizaki ${ }^{1}$, Hidetoshi Kimura ${ }^{1}$, Maki Kitahara $^{3}$, Yasuhiro Fujino ${ }^{2}$, Sadahiro Ohmomo ${ }^{4}$, \\ Toshihisa Ohshima ${ }^{1}$ and Seiya Ogata ${ }^{1}$
}

\begin{abstract}
To develop high-quality silage starters adapted to hot and humid weather, 12 LAB isolates from silage produced in Kyushu and Okinawa, Japan were characterized based on their morphological features, growth curves and sugar utilization. In addition, the nucleotide sequences of the V2-V3 region of their 16S rRNA genes and the 16S-23S rRNA intergenic spacer (ITS) regions were determined. The isolates were also subjected to RAPD-PCR analysis, DNA-DNA hybridization, $\mathrm{G}+\mathrm{C}$ content analysis and immuno-identification using species-specific monoclonal antibodies and SDS-PAGE profiling. Nearly all of the isolates exhibited high thermotolerance and rapid growth. Combining ITS sequence analysis, RAPD-PCR and immuno-identification enabled rapid and accurate identification of closely related $L A B$ strains that other methods failed to appropriately differentiate; for example, L. plantarum was distinguished from L. pentosus, and L. casei was distinguished from L. rhamonsus. Using the aforementioned techniques, the isolated strains were identified as L. plantarum, L. rhamonsus, L. rapi, Pediococcus pentosaceus and P. Iolii. Our findings also showed that there is greater diversity among thermophilic LABs in silage prepared in a hot and humid environment.
\end{abstract}

Keywords: Lactic acid bacteria; Lactobacillus; Pediococcus; Silage; Hot and humid environment

\section{Introduction}

Silage is a storable fodder typically produced through a sequential microbial process involving homofermentative lactic acid bacteria (LAB) such as Lactobacillus plan tarum, Lactococcus lactis, Leuconostoc pseudomesenteroides, Pediococcus acidilactici and Enterococcus faecalis (Cai et al. 1999; Ennahar et al. 2003; Giraffa et al. 2010). In recent years, the demand for dairy products has increased in many developing countries in the tropical and subtropical regions of Asia and Africa; however, production of the silage necessary for dairy farming has been hindered in these regions because the ensiling process is dependent on local environmental conditions (Namihira et al. 2010). For example, virtually all of the many available silage starters (Holzer et al. 2003; Yan et al. 2008) are hampered

\footnotetext{
* Correspondence: doi@agr.kyushu-u.ac.jp

'Microbial Genetic Division, Institute of Genetic Resources, Faculty of Agriculture, Kyushu University, 6-10-1 Hakozaki, Higashi-ku, Fukuoka 812-8581, Japan

Full list of author information is available at the end of the article
}

by high temperatures and humidity (Ohmomo et al. 2002; Mulrooney and Kung 2008). This is in part because the phage infections that occur in hot humid weather reduce the viability of LAB (Kaneshige et al. 1994). At present, therefore, there is a strong need to identify starter strains suitable for use in hot climates.

The islands of Kyushu and Okinawa in southwestern Japan have a humid, subtropical climate. Production of high-quality silage there is difficult due to unbroken periods of extremely hot days, with temperatures exceeding $30^{\circ} \mathrm{C}$ in summer, and to the high moisture content (over $80 \%$ ) in the plant materials. Stable production of high-quality silage in these regions will require the identification and application of acid-tolerant, thermophilic LAB or homolactic acid fermented LAB as starter strains (Mulrooney and Kung 2008). Given the limits of the available technology, however, the screening, selection and construction of starter cultures for silage making remains a challenge, as classification of isolated strains is still difficult. In particular, closely related species, such 
as L. plantarum, L. casei, L. rhanmosus and L. pentosus, which are the main dominant strains in silage, are difficult or impossible to distinguish on the basis of their phenotypes and genotypes (Hammes and Hertel 2006). Some PCR amplification methods for the 16S-23S rRNA, recA and $d n a K$ genes have been used to identify L. plantarumrelated species (Torriani et al. 2001; Huang et al. 2010; Ouoba et al. 2010), but there is no generally accepted or systematic approach to identification of silage-making lactobacilli. In particular, there have been few studies characterizing LAB strains grown in silage produced in tropical or subtropical regions (Namihira et al. 2010).

Here, we report the isolation and characterization of LAB from silage produced in Okinawa, Japan. We used various identification methods to assess the diversity of silage-making LAB in subtropical areas, and to identify species closely related to $L$. plantarum and $L$. pentosus and to L. casei and L. rhamonsus. Our findings represent the first use of immuno-identification for the identification of LAB from silage.

\section{Materials and methods}

\section{Bacterial strains and culture conditions}

Twelve representative LAB strains isolated from silage prepared in Okinawa prefecture, Japan were used. $L$. brevis JCM $1059^{\mathrm{T}}$, L. casei JCM 1134 ${ }^{\mathrm{T}}$, L. fermentum JCM $1173^{\mathrm{T}}$, L. kefiri JCM $5818^{\mathrm{T}}$, L. parakefiri JCM $8573^{\mathrm{T}}$, L. paraplantarum JCM $12533^{\mathrm{T}}$, L. plantarum JCM 1057, L. plantarum JCM $1149^{\mathrm{T}}$, L. rapi JCM $15042^{\mathrm{T}}$, L. rhanmosus JCM $1136^{\mathrm{T}}$, L. pentosus JCM $1558^{\mathrm{T}}$, Pediococcus acidilactici JCM $8797^{\mathrm{T}}$ and P. pentosaceus JCM $5890^{\mathrm{T}}$ were used as reference strains. Escherichia coli $\mathrm{DH} 5 \alpha$ was used as a host strain for plasmid vector pTA2 (Toyobo Co., Ltd., Osaka, Japan).

Bacto $^{\text {тм }}$ Lactobacilli MRS Broth (Becton, Dickinson and Company, NJ, USA) and agar plates (2.0\% agar) were used for transplantation and growth of Lactobacillus strains. GAM Broth (Nissui Pharmaceutical Co., Tokyo, Japan) and R-CW agar (Kojima et al. 1993) were used for growth of $P$. pentosaceus JCM $5890^{\mathrm{T}}$ and L. parakefir JCM $8573^{\mathrm{T}}$, respectively. L. kefir JCM $5818^{\mathrm{T}}$, L. parakefir JCM $8573^{\mathrm{T}}$, L. pentosus JCM $1558^{\mathrm{T}}$, L. plantarum JCM 1057, L. plantarum JCM $1149^{\mathrm{T}}$ and P. acidilactici JCM $8797^{\mathrm{T}}$ were cultivated at $30^{\circ} \mathrm{C}$ under anaerobic conditions. Cultivation of other strains was carried out at $37^{\circ} \mathrm{C}$ under anaerobic conditions. A microaerobic condition $\left(5 \% \mathrm{O}_{2}\right.$, $10 \% \mathrm{CO}_{2}, 85 \% \mathrm{~N}_{2}$ ) for cultivation of $L$. paraplantarum ATCC $700211^{\mathrm{T}}$ was generated using AnaeroPack Plus (Mitsubishi Gas Chemical Co., Tokyo, Japan). LB broth and agar plates $(2.0 \%)$ were used for growth and transformation of $E$. coli. LB plates containing ampicillin (100 $\mu \mathrm{g} / \mathrm{ml})$, isopropyl- $\beta$-D-thiogalactopyranoside $(120 \mathrm{D} \mu \mathrm{g} / \mathrm{ml})$ and 5-bromo-4-chloro-3-indolyl- $\beta$-D-galactopyranoside
(400 D $\mu \mathrm{g} / \mathrm{ml}$ ) were used for selection of blue/white colonies.

\section{Physiological characterization}

The shapes of all isolates were observed using an Axioskop phase-contrast microscope (Carl Zeiss, Ober kochen, Germany) and transmission electron microscopy (JEM 2000 EX; JEOL, Tokyo, Japan). Gas formation from glucose, fermentation type, lactic acid production, and peptidoglycan type were examined as described previously (Tanaka et al. 1994). In addition, the characteristics of the carbohydrate fermentation by all strains were determined using an API 50CHL kit (BioMérieux, Montalieu Vercie, France). Growth curves for the isolates were constructed using Miniphoto 518 (TAITEC Corporation, Saitama, Japan) by monitoring the optical density at $660 \mathrm{~nm}$.

\section{Total DNA extraction}

Total DNA was isolated from LAB strains cultured overnight in $600 \mathrm{ml}$ of liquid medium supplemented with $0.5 \%$ glycine. After washing the cells with wash buffer (50 mM Tris-HCl, 150 mM NaCl, 100 mM EDTA; pH $8.0)$, they were collected by centrifugation and lysed in $10 \mathrm{ml}$ of lysis buffer (50 mM Tris- $\mathrm{HCl}, 10 \mathrm{mM}$ EDTA, $10 \mathrm{mg} / \mathrm{ml}$ lysozyme (Seikagaku Corporation, Tokyo, Japan), $2 \mathrm{mg} / \mathrm{ml} \mathrm{N}$-acetylmuramidase SG (Seikagaku Corporation), $100 \mu \mathrm{g} / \mathrm{ml}$ RNase A; $\mathrm{pH}$ 8.0). The lysate was then added to $200 \mathrm{ml}$ of $25 \%$ sodium dodecyl sulfate (SDS) and incubated for $2 \mathrm{~h}$ at $37^{\circ} \mathrm{C}$, after which the DNA was extracted first in phenol-chloroform-isoamyl alcohol (25:24:1) and then in chloroform-isoamyl alcohol (24:1). The extracted DNA was then precipitated in isopropanol, collected and dissolved in $100 \mathrm{ml}$ of TE buffer.

\section{PCR amplification and cloning amplified fragments}

The primers used in this study are listed in Table 1. To amplify the V2-V3 regions of $16 \mathrm{~S}$ rRNA and the $16 \mathrm{~S}-23 \mathrm{~S}$ intergenic spacer (ITS) region, primers were designed as described by Tannock et al. (1999). With all primer sets, PCR was carried out in a $50-\mu \mathrm{l}$ reaction volume containing $5 \mathrm{U}$ of KOD DNA polymerase (Toyobo), $5 \mu \mathrm{l}$ of $10 \times \mathrm{PCR}$ reaction buffer, $0.2 \mathrm{mM}$ each primer, $0.2 \mathrm{mM}$ dNTPs, 0.5 $\mathrm{mM} \mathrm{MgCl} 2$ and $200 \mathrm{ng}$ of purified genomic DNA. The amplified products were separated on $2.0 \%$ agarose gels containing $1 \times$ TAE electrophoresis buffer, purified using a Cyclo-Pure Gel Extraction Kit (AMRESCO Inc., Solon, $\mathrm{OH}, \mathrm{USA})$ according to the manufactures' instructions, and then ligated to pTA2 vector using a Takara BKL Kit (Takara Bio Inc., Shiga, Japan). The recombinant DNAs to be transformed into E. coli $\mathrm{DH} 5 \alpha$ competent cells were extracted and purified through alkaline lysis using QIAGEN-tip 20 (QIAGEN GmbH, Hilden, Germany). 
Table 1 Primers used in this study

\begin{tabular}{lllll}
\hline Primer & Sequence $\left(\mathbf{5}^{\prime}\right.$ to $\mathbf{3}^{\prime}$ ) & Use & Specificity or target & Reference or source \\
\hline HDA1 & ACTCCTACGGGAGGCAGCAGT & PCR & V2-V3 region of 16SrRNA & Tannock et al. (1999) \\
HDA2 & GTATTACCGCGGCTGCTGGCAC & PCR & V2-V3 region of 16SrRNA & Tannock et al. (1999) \\
16A-1 & GAATCGCTAGTAATCG & PCR & 16S-23S intergeneic spacer region & Tannock et al. (1999) \\
23B-1 & GGGTTCCCCATTCGGA & PCR & 16S-23S intergeneic spacer region & Tannock et al. (1999) \\
M13 Primer M3 & GTAAA ACGACGGCCAGT & DNA sequence & Plasmid vector pTA2 & TaKaRa Bio \\
M13 Primer RV & CAGGA AACAGCTATGAC & DNA Sequence & Plasmid vector pTA2 & TaKaRa Bio \\
AP-A-2 & TGGATTGGTC & & This study \\
AP-A-6 & AAACTCCGTC & RAPD & This study \\
AP-A-8 & TGGTAAAGGG & RAPD & & This study \\
AP-A-19 & GATCATAGCC & RAPD & & This study \\
AP-A-23 & GATCTGACTG & RAPD & & This study \\
\hline
\end{tabular}

\section{Nucleotide sequence analysis}

Nucleotide sequences were determined using a Thermo Sequenase fluorescently labeled primer cycle sequencing kit with 7-deaza-dGTP (GE Healthcare Bio-Sciences, Uppsala, Sweden) and ALF express II DNA sequencer. The sequences of the amplified DNA were scanned based on data registered in databases using GENETIXMAC ver. 15 (GENETYX, Tokyo, Japan). Comparisons between the sequences and the databases were made using the Blast program (http://blast.ncbi.nlm.nih.gov/ Blast.cgi). Multiple alignments and phylogenetic analyses were accomplished using ClustalW ver. 2.1 (http://clustalw. ddbj.nig.ac.jp/) and the neighbor-joining (NJ) method. Evolutionary distance values were estimated using Kimura's 2 parameter method.

\section{RAPD analysis}

RAPD-PCR analyses were performed as described previously (Fujino et al. 2008) using a single 10-mer random primer listed in Table 1 and $0.5 \mathrm{U}$ of Gene Taq FP polymerase (Nippongene, Toyama, Japan). The PCR protocol entailed initial denaturation at $95^{\circ} \mathrm{C}$ for $5 \mathrm{~min}$, followed by 35 cycles of 1 min denaturation at $95^{\circ} \mathrm{C}$, annealing $36^{\circ} \mathrm{C}$ for $1 \mathrm{~min}$ and extension for $2 \mathrm{~min}$ at $72^{\circ} \mathrm{C}$, and a final extension for $5 \mathrm{~min}$ at $72^{\circ} \mathrm{C}$. RAPD-PCR products were analyzed by electrophoresis run on $2.0 \%$ agarose gels in $1 \mathrm{X}$ TAE for $1 \mathrm{~h}$ at $100 \mathrm{~V}$.

\section{SDS-PAGE profiling}

SDS-PAGE was carried out using an AE-6200 electrophoresis unit (ATTO, Tokyo, Japan) to determine the size and number of whole proteins in the isolates. Electrophoresis was carried using the method of Laemmli (1970). Samples were boiled for $10 \mathrm{~min}$ at $100^{\circ} \mathrm{C}$ in SDS-PAGE buffer (125 $\mathrm{mM}$ Tris- $\mathrm{HCl}$ (pH 6.8), 10\% 2-mercaptoethanol, 4\% SDS, $10 \%$ glycerol, $0.004 \%$ bromophenol blue) to ensure denaturation before being loaded onto the gel. Each well was loaded with $20 \mu \mathrm{l}$ of sample containing approximately
$10 \mu \mathrm{g}$ of protein. After electrophoresis, the gels were stained with Coomassie blue R-250, destained using 7.5\% glacial acetic acid and 5\% methanol, and then photographed. Numerical analysis of the protein pattern was performed using the GelCompar system (version 4.0; Applied Maths, Sint-Martens-Latem, Belgium), which normalizes fragment pattern data for band intensity, after which the relative band position is compared to molecular weight standards. The similarities between all pairs were expressed using a pair-group method with arithmetic averages (UPGMA) for construction of the dendrogram. All strains were analyzed at least three times to ensure the reproducibility of the fingerprinting pattern.

\section{Immuno-identification}

For identification using monoclonal antibodies, anti- L. casei monoclonal antibody (72-6D2) and anti-L. plantarum monoclonal antibody (55-1C3) (Asahi Food \& Healthcare Co., ltd., Tokyo, Japan) were used as primary antibodies, and an affinity purified, horseradish peroxidase-conjugated rabbit anti-mouse IgG $_{1}$ (MP Biomedicals, Solon, $\mathrm{OH}$, USA) was used as the secondary antibody. LAB were incubated until late log growth phase and washed with TES buffer $(50 \mathrm{mM} \mathrm{NaCl}, 30 \mathrm{mM}$ Tris- $\mathrm{HCl}, 5$ mM EDTA; pH 8.0), after which they were suspended in TES buffer at an optical density of 1.0 at $660 \mathrm{~nm}$. Aliquots $(100 \mathrm{ml})$ of the suspension were then incubated overnight at $4^{\circ} \mathrm{C}$ in a 96 -well microtiter plate. To determine the dose response relationship, various numbers of bacteria were inoculated onto similar microtiter plates. After washing with Tween-PBS (phosphate-buffered saline (137 mM NaCl, $2.7 \mathrm{mM} \mathrm{KCl,} \mathrm{8.1} \mathrm{mM} \mathrm{Na}_{2} \mathrm{HPO}_{4}$ and 1.5 $\mathrm{mM} \mathrm{KH_{2 }} \mathrm{PO}_{4}$ ) supplemented with $0.1 \%$ Tween 20), the plates were blocked by incubation for $1 \mathrm{~h}$ at $37^{\circ} \mathrm{C}$ with 120 $\mathrm{ml}$ of carbonate buffer containing $1 \%$ bovine serum albumin (BSA). The plates were then washed three times and treated for $2 \mathrm{~h}$ at $37^{\circ} \mathrm{C}$ with $100 \mathrm{ml}$ per well of appropriate dilutions of monoclonal antibodies in Tween-PBS with 1\% 
BSA. The plates were then washed again and treated for 2 $\mathrm{h}$ at $37^{\circ} \mathrm{C}$ with $100 \mathrm{ml}$ of a 1:1000 dilution of secondary antibody in Tween-PBS with 1\% BSA. After washing, the plates were treated with $100 \mathrm{ml}$ of the coloring agent (100 $\mathrm{mM}$ citric acid, $200 \mathrm{mM} \quad \mathrm{Na}_{2} \mathrm{HPO}_{4}, \quad 10 \%$ DMSO containing $2 \% 3,3$ ', 5, 5', tetramethylbenzidine, $0.02 \%$ $\mathrm{H}_{2} \mathrm{O}_{2}$ (30\% aqueous); $\mathrm{pH} 6.2$ ) for $10 \mathrm{~min}$ at $37^{\circ} \mathrm{C}$ and finally with $50 \mathrm{ml}$ per well of $2 \mathrm{M}$ sulfuric acid to stop the reaction.

\section{$\mathrm{G}+\mathrm{C}$ content and DNA-DNA hybridization}

To determine the genomic $\mathrm{G}+\mathrm{C}$ content, extracted DNA was purified by ultracentrifugation (Optima TMX Ultracentrifuge, Beckman Coulter Inc.) for $24 \mathrm{~h}$ at $80,000 \times g$ in cesium chloride $(1 \mathrm{~g} / \mathrm{ml})$ and ethidium bromide $(0.8 \mathrm{mg} / \mathrm{ml})$. The DNA was then dissolved in ultrapure distilled water, and the ethidium bromide was removed with isopropanol, after which the $\mathrm{G}+\mathrm{C}$ content of the purified DNA was determined using DNA-GC kits (YamasaShouyu, Chiba, Japan) according to the manufacturer's instructions. The nucleoside mixture obtained was then separated by HPLC (model 600E, Waters Corporation, Massachusetts, MA, USA) using a YMC pack AQ-312 column (YMC Co., Ltd., Kyoto, Japan). The mobile phase consisted of $10 \mathrm{mM} \mathrm{H}_{3} \mathrm{PO}_{4}$ and $10 \mathrm{mM} \mathrm{KH}_{2} \mathrm{PO}_{4}$ (pH3.5). As a control, genomic DNA from phage $\lambda$ was analyzed along with the sample.

DNA-DNA hybridization was carried out as described previously (Ezaki et al. 1989; Adnan et al. 1993). Samples of purified DNA from each of the 12 isolated and 6 type strains were suspended in TE buffer $(100 \mu \mathrm{g} / \mathrm{ml})$ and denatured at $100^{\circ} \mathrm{C}$ for $5 \mathrm{~min}$. Ice-cold PBS $(8 \mathrm{mM}$ $\mathrm{Na}_{2} \mathrm{HPO}_{4}, 1.5 \mathrm{mM} \mathrm{KH} \mathrm{PO}_{4}(\mathrm{pH} 7.2), 137 \mathrm{mM} \mathrm{NaCl}$, $2.7 \mathrm{mM} \mathrm{KCl}$ ) containing $0.1 \mathrm{M} \mathrm{MgCl}_{2}$ was then added to the DNA solution to a final concentration of $10 \mu \mathrm{g} / \mathrm{ml}$, and aliquots of the resultant single-stranded DNA solution $(100 \mu \mathrm{l} /$ well) were dispensed into a FluoroNunc Plate (Thermo Fisher Scientific Inc., Waltham, MA, USA). The plate was then sealed and incubated for $3 \mathrm{~h}$ at $28^{\circ} \mathrm{C}$, after which the mixture was discarded and the plate was dried overnight at $48^{\circ} \mathrm{C}$. Photobiotin-labeled DNA was then prepared using a PHOTOPROBE (VECTOR lab., Burlingame, CA, USA) according to the manufacturer's instructions. About $25 \mathrm{ng}$ of labeled DNA were distributed into each well of a microplate, and hybridization was carried out at for $3 \mathrm{~h}$ at $40^{\circ} \mathrm{C}$ in the hybridization mixture $(2 \times \mathrm{SSC}$, $5 \times$ Denhardt, $3 \%$ dextran sulfate, $50 \%$ formamide and $200 \mu \mathrm{g}$ of denatured salmon sperm DNA). Streptavidinconjugated horseradish peroxidase (Thermo Fisher Scientific Inc.) was diluted 2000-fold in PBS containing 0.5\% bovine serum albumin and $0.1 \%$ Triton $X-100$, and $100 \mu 1$ of the diluted enzyme solution were added to each well. The plate was then incubated for $30 \mathrm{~min}$ at $37^{\circ} \mathrm{C}$ and washed three times in $300 \mu 1$ of $2 x S S C$. After washing, $100 \mu 1$ of chromogenic substrate solution (0.1 M citric acid-0.2 M $\mathrm{Na}_{2} \mathrm{HPO}_{4}$ (pH 6.2)-10\% DMFO containing of 2\% 3, 3', 5, 5', tetramethylbenzidine in DMFO and $2 \% \mathrm{H}_{2} \mathrm{O}_{2}$ aqueous $(0.3 \%))$ were added to each well. After incubating the samples and standards for $10 \mathrm{~min}$, the absorbance at $655 \mathrm{~nm}$ was read on a Multiskan FC microplate reader (Thermo Fisher Scientific Inc.).

\section{Results}

Phenotypic characterization of the isolates

All of the isolates grew in MRS broth at $30-43^{\circ} \mathrm{C}$, and strains NGRI 0001, 0110 and 0130 grew at $45^{\circ} \mathrm{C}$ (data not shown). When cultivated at $37^{\circ} \mathrm{C}$, strains NGRI 0101 and 0529 reached the stationary phase within $8 \mathrm{~h}$ after inoculation (Figure 1). With the exception of strains NGRI 0130 and 0305 , the isolated strains were homofermentative and did not produce gas from glucose. The peptidoglycans of strains NGRI 0110, 0130, 0304 and 0305 were the non-diamino pimericacid type, while those of the other strains were diamino pimericacid. None of the strains was able to assimilate soluble starch, and the sugar utilization properties of strains NGRI 0001, 0315 and 0524 were identical. Based on their properties, strain NGRI 0110 was coarsely categorized as a L. casei group, and strains NGRI 0001, 0101, 0225, 0315, 0404, 0524 and 0529 were categorized as a L. plantarum group. Strains NGRI 0304, 0305 and 0510 were grouped together as Pediococcus species. That said, the properties of the isolates were not all identical to those of the reference strains.

\section{Analysis of the V2-V3 variable region of 16S rDNA and the 16S-23S rDNA ITS region}

An approximately 200-bp band amplified using primers HDA1 and HDA2 was detected in all LAB isolates tested (data not shown). The nucleotide sequences from the isolated strains NGRI 0225, 0304, 0305, 0315, 0404, 0524 and 0529 showed $100 \%$ identity to those of $L$. plantarum, L. paraplantarum and L. pentosus. The highest sequence homology shown by strain NGRI 0110 was $99 \%$ to L. casei, L. paracasei subsp. tolerans and $L$. rhamnosus, while strain NGRI 0510 showed 99\%, 98\% and $92 \%$ identity to $P$. acidilactici, $P$. pentosaceus and $P$. damnosus, respectively. The nucleotide sequence in the V2-V3 region of strain NGRI 0001 perfectly matched that of $L$. kefri. The sequences from strain NGRI 0130 showed significant identity to the V2-V3 regions of $L$. rapi and $L$. parabuchneri. Using these partial 16S rRNA sequences, we constructed a phylogenetic tree (Figure 2(A)). Four clusters were formed at a similarity level of $97 \%$, with the L. plantarum cluster containing the largest number of isolates (8) and the $L$. casei cluster containing the fewest (1). Strains NGRI 0001 and 0130 were categorized in the L. kefri cluster. 

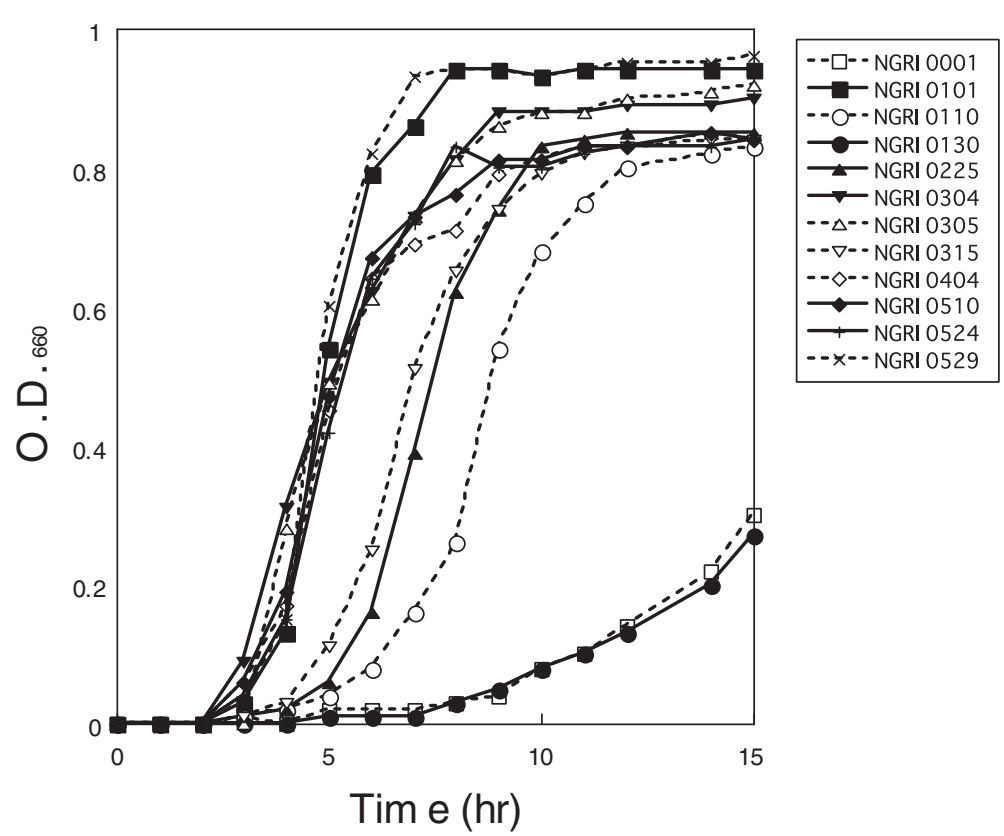

Figure 1 Growth curves for isolated silage-making LABs. Cells were grown at $37^{\circ} \mathrm{C}$ for $15 \mathrm{~h}$ in MRS media and monitored based on absorbance at $660 \mathrm{~nm}$. Relative cell densities are an average of four independent cultures.

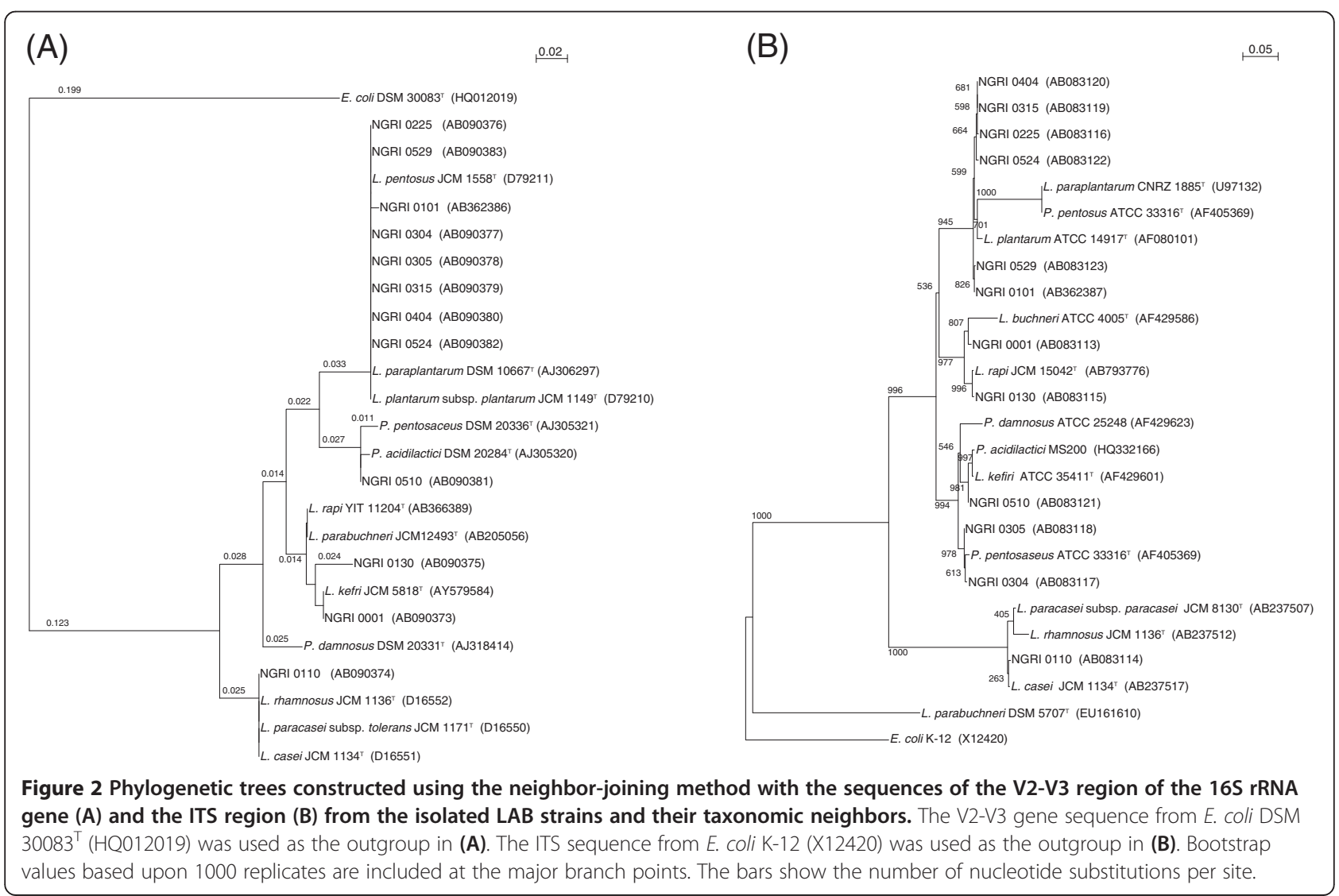


Amplification of the ITS region using primers 16A-1 and 23B-1 yielded an approximately 540-bp band with all samples tested (data not shown). The ITSs of strains NGRI 0225, 0315, 0404 and 0524, showed 99\%, 100\% and $100 \%$ identity to those of L. plantarum, L. pentosus and $L$. paraplantarum, respectively, while the ITSs of strains NGRI 0304 and 0305 showed 99\%, 95\% and 92\% identity to the those of $P$. pentosaceus, $P$. acidilactici and $P$. damnosus, respectively. Using the ITS sequences, we constructed a phylogenic tree, which included four clusters: an L. plantarum group, L. casei group, L. buchneri group and Pediococcus group (Figure 2(B)).

The dendrograms for both the V2-V3 and ITS regions did not separate the positions of strains closely related on the evolutionary tree, such as among L. plantarum, $L$. paraplantarum and L. pentosus, or among L. casei, $L$. paracase $i$ and $L$. rhanmosus. The sequences of the $16 \mathrm{~S}$ rRNA V2-V3 regions of strains NGRI 0101, 0315, 0404, 0524 and 0529 were identical to those of $L$. para plantarum, L. pentosus and L. plantarum. However, the isolated strains were able to utilize raffinose, which is not fermented by $L$. paraplantarum (Curk et al. 1996) (Table 2). Therefore, these strains should be $L$. pentosus or L. plantarum. The V2-V3 and ITS sequences of the isolates have been deposited in the DNA Data Bank of Japan (DDBJ) under accession numbers AB090373 to AB090383 and AB083113 to AB083123, respectively.

\section{Genotyping using RAPD-PCR profiles}

RAPD-PCR analyses were performed using single oligonucleotide primers (10 mer). No amplified fragment was generated with the AP-A- 6 or AP-A-8 primer (data not shown). On the other hand, the genotypes obtained with the AP-A-2 (Figure 3(A)), AP-A-19 (data not shown) and AP-A-23 (Figure 3(B)) primers were completely consistent with the phenotypes of the isolates. The amplified patterns were detectable in all isolates and reference strains, and RAPD-PCR profiles recognized some clusters. In Figure 3(A), a $0.5-\mathrm{kb}$ fragment (arrowhead a) was amplified in the L. plantarum strains JCM 1057 and JCM 1149 ${ }^{\mathrm{T}}$ (lanes 13

Table 2 Characteristics of isolated strains

\begin{tabular}{|c|c|c|c|c|c|c|c|c|c|c|c|c|}
\hline Strain & $\begin{array}{l}\text { NGRI } \\
0001\end{array}$ & $\begin{array}{l}\text { NGRI } \\
0101\end{array}$ & $\begin{array}{l}\text { NGRI } \\
0110\end{array}$ & $\begin{array}{l}\text { NGRI } \\
0130\end{array}$ & $\begin{array}{l}\text { NGRI } \\
0225\end{array}$ & $\begin{array}{l}\text { NGRI } \\
0304\end{array}$ & $\begin{array}{l}\text { NGRI } \\
0305\end{array}$ & $\begin{array}{l}\text { NGRI } \\
0315\end{array}$ & $\begin{array}{l}\text { NGRI } \\
0404\end{array}$ & $\begin{array}{l}\text { NGRI } \\
0510^{*}\end{array}$ & $\begin{array}{l}\text { NGRI } \\
0524\end{array}$ & $\begin{array}{l}\text { NGRI } \\
0529\end{array}$ \\
\hline Shape & Rods & Rods & Rods & Rods & Rods & Cocci & Cocci & Rods & Rods & Cocci & Rods & Rods \\
\hline Gas from glucose & - & - & - & + & - & - & + & - & - & - & - & - \\
\hline Growth at $15^{\circ} \mathrm{C}$ & + & + & + & + & + & + & + & + & + & + & + & + \\
\hline Growth at $45^{\circ} \mathrm{C}$ & + & - & + & + & - & - & - & - & - & - & - & - \\
\hline Fermentation type & Homo & Homo & Homo & Hetero & Homo & Homo & Hetero & Homo & Homo & Homo & Homo & Homo \\
\hline Lactate formed & $\mathrm{DL}$ & $\mathrm{DL}$ & $L$ & $\mathrm{DL}$ & $\mathrm{DL}$ & $L$ & $\mathrm{DL}$ & $\mathrm{DL}$ & $\mathrm{DL}$ & $\mathrm{DL}$ & $\mathrm{DL}$ & $\mathrm{DL}$ \\
\hline $\begin{array}{l}\text { Peptidoglycan } \\
\text { type }\end{array}$ & $\mathrm{A}_{2} \mathrm{pm}$ & $\mathrm{A}_{2} \mathrm{pm}$ & $\begin{array}{l}\text { Non- } \\
\mathrm{A}_{2} \mathrm{pm}\end{array}$ & $\begin{array}{l}\text { Non- } \\
\mathrm{A}_{2} \mathrm{pm}\end{array}$ & $\mathrm{A}_{2} \mathrm{pm}$ & $\begin{array}{l}\text { Non- } \\
\mathrm{A}_{2} \mathrm{pm}\end{array}$ & $\begin{array}{l}\text { Non- } \\
\mathrm{A}_{2} \mathrm{pm}\end{array}$ & $\mathrm{A}_{2} \mathrm{pm}$ & $\mathrm{A}_{2} \mathrm{pm}$ & $\mathrm{A}_{2} \mathrm{pm}$ & $\mathrm{A}_{2} \mathrm{pm}$ & $\mathrm{A}_{2} \mathrm{pm}$ \\
\hline \multicolumn{13}{|l|}{ Acid from: } \\
\hline Na-Gluconate & + & + & + & + & + & + & + & + & + & + & + & + \\
\hline L- Arabinose & + & - & + & + & - & + & + & + & + & + & + & + \\
\hline Lactose & + & + & + & - & + & - & - & + & + & - & + & + \\
\hline Galactose & + & + & + & - & + & + & + & + & + & + & + & + \\
\hline Sucrose & + & + & + & - & + & + & + & + & + & - & + & + \\
\hline Mannose & + & + & + & - & + & + & + & + & + & + & + & + \\
\hline Fructose & + & + & + & - & + & + & + & + & + & + & + & + \\
\hline Soluble starch & - & - & - & - & - & - & - & - & - & - & - & - \\
\hline D-Xylose & + & - & - & + & - & - & + & + & + & + & + & + \\
\hline D-Ribose & + & + & + & + & + & + & + & + & + & + & + & + \\
\hline Mannitol & + & + & + & - & + & - & + & + & + & + & + & + \\
\hline Sorbitol & + & + & + & - & + & + & - & + & + & + & + & + \\
\hline Rhamnose & + & - & + & - & - & + & - & + & - & + & + & - \\
\hline Trehalose & + & + & + & - & + & + & + & + & + & - & + & + \\
\hline Raffinose & + & + & - & + & + & + & + & + & + & - & + & + \\
\hline $\begin{array}{l}\text { DNA G+C content } \\
(\%)\end{array}$ & 45.1 & 45.3 & 47.3 & 46.2 & 45.1 & 39.7 & 39.0 & 44.4 & 45.1 & 41.0 & 46.1 & 44.0 \\
\hline
\end{tabular}

*Data was obtained from Doi et al (2009). 

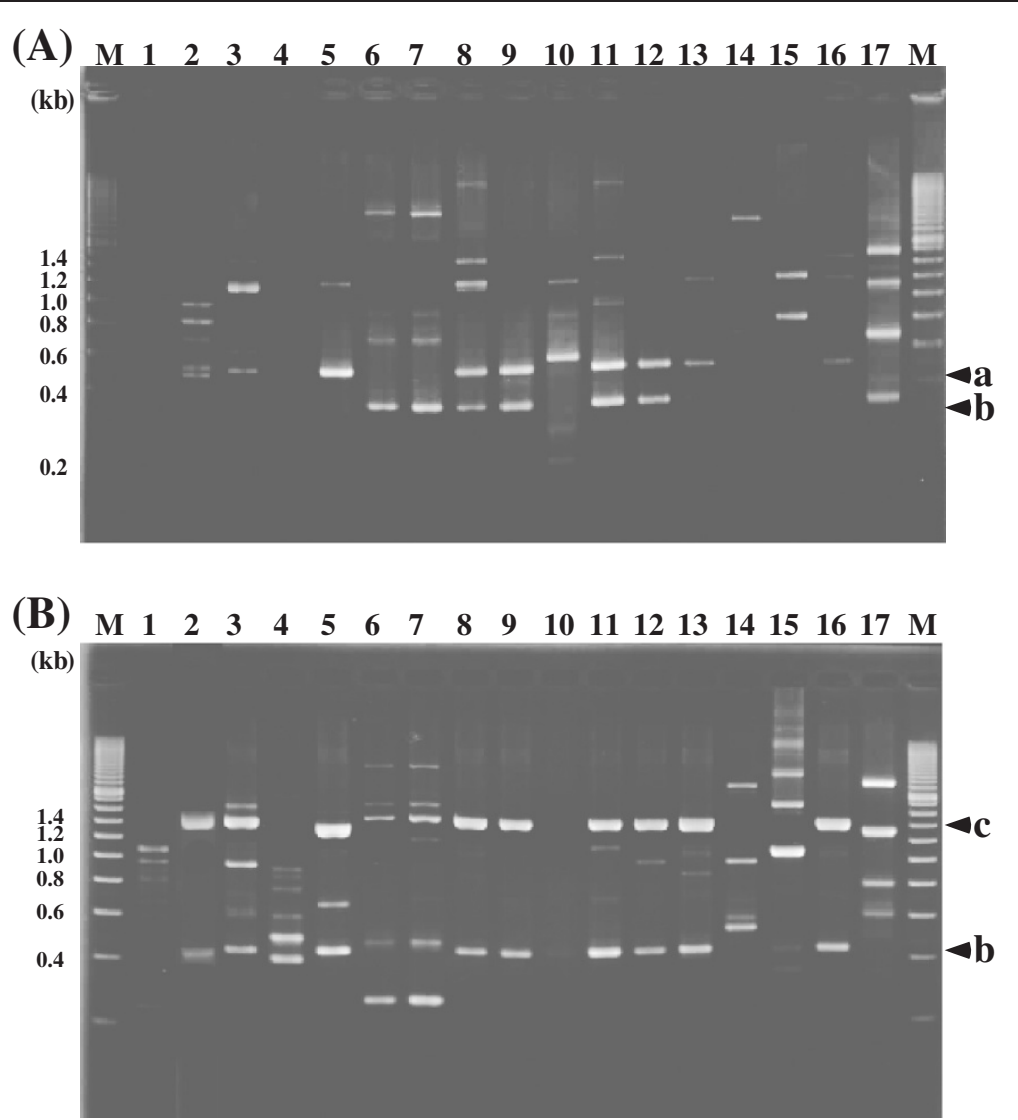

Figure 3 RAPD-PCR fingerprinting of isolated strains and related species using primers AP-A-2 (A) and AP-A-23 (B). Lanes: M, size markers (200 bp DNA ladder; TOYOBO); 1, NGRI 0001; 2, NGRI 0101; 3, NGRI 0110; 4, NGRI 0130; 5, NGRI 0225; 6, NGRI 0304; 7, NGRI 0305; 8, NGRI 0315; 9, NGRI 0404; 10, NGRI 0510; 11, NGRI 0524; 12, NGRI 0529; 13, L. plantarum JCM 1057; 14, L. casei JCM 1134 ; 15, L. rhamnosus JCM 1136'; 16, L. plantarum JCM $1149^{\top}$; 17, L. pentosus JCM $1558^{\top}$.

and 16) using primer AP-A-2, and equal-sized bands were observed in lanes $2,3,5,8,9,11,12$ and 13 , suggesting the amplified fragments are common to all L. plantarum strains. Although amplification of a $0.3-\mathrm{kb}$ fragment (arrowhead b) was also observed in lanes 6, 7, 8, 9, 11, 12 and 17, no other amplified fragments were identical to $L$. pentosus JCM $1558^{\mathrm{T}}$ (lane 17). Moreover, the profiles of strains NGRI 0304 and 0305 (lanes 6 and 7) were virtually identical to one another, but did not resemble the profiles of any other strains. In Figure 3(B), two major bands, at $1.4 \mathrm{~kb}$ (arrowhead c) and $0.4 \mathrm{~kb}$ (arrowhead d), appeared in the L. plantarum JCM 1057 (lane 13) and L. plantarum JCM $1149^{\mathrm{T}}$ (lane 16) profiles obtained using primer AP-A23. Similar patterns were observed with strains NGRI 0101, 0225, 0315, 0404, 0524 and 0529 (lanes 2, 5, 8, 9, 11 and 12), suggesting these major amplified bands are indicative of the L. plantarum group.

\section{Immuno-identification using anti-lactobacilli antibodies}

The antigenicity of the LAB isolates to anti-L. plantarum and anti- $L$. casei antibodies was assessed using an enzyme-linked immunosorbent assay (ELISA). Six samples from silage (NGRI 0101, 0225, 0315, 0404, 0524 and 0529) and three reference samples (L. plantarum strains JCM 1057 and JCM $1149^{\mathrm{T}}$, and L. pentosus JCM $1558^{\mathrm{T}}$ ) reacted positively with the anti-L. plantarum antibody (Figure 4(A)). In addition, one reference sample ( $L$. casei JCM $1134^{\mathrm{T}}$ ) reacted with the anti- $L$. casei antibody. L. rhamnosus JCM $1136^{\mathrm{T}}$, which is a $L$. casei-related strain, showed a negative response to the antibody (Figure 4(B)). Among the LAB isolates tested, only NGRI 0110 cells showed faint positivity for the anti- $L$. casei antibody. These results suggest that the anti-L. casei antibody tested could differentiate between $L$. casei and L. rhamnosus, and that there was no strain which could be identified as $L$. casei among the $12 \mathrm{LAB}$ isolates.

\section{Whole-cell protein fingerprinting}

Whole-cell protein fingerprinting of the 12 isolates and 5 reference strains yielded distinctly different band patterns (Figure 5), with an intragel reproducibility of approximately $90 \%$. Numerical analysis of the SDS-PAGE patterns obtained with the isolated strains resolved 5 clusters (A-E), emerging at a similarity level of $60 \%$, and confirmed 


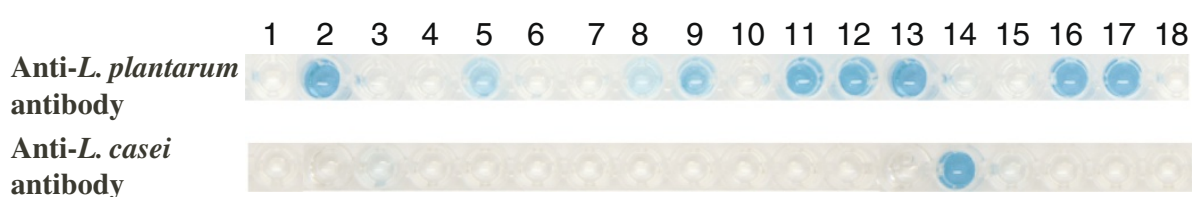

Figure 4 Immuno-identification of $L$. plantarum and $L$. casei group strains. Lanes: 1, NGRI 0001; 2, NGRI 0101; 3, NGRI 0110; 4, NGRI 0130; 5 , NGRI 0225; 6, NGRI 0304; 7, NGRI 0305; 8, NGRI 0315; 9, NGRI 0404; 10, NGRI 0510; 11, NGRI 0524; 12, NGRI 0529; 13, L. plantarum JCM 1057; 14, L. casei JCM 1134'; 15, L. rhamnosus JCM 1136 $;$; 16, L. plantarum JCM 1149 $;$; 17, L. pentosus JCM 1558 ${ }^{\top}$; 18, E. coli DH5a.

the phenotypic characterization of the isolates. Cluster A includes L. plantarum and L. pentosus, while cluster C includes L. casei and L. rhamnosus.

\section{Analysis of $\mathrm{G}+\mathrm{C}$ content and DNA-DNA relatedness}

The $\mathrm{G}+\mathrm{C}$ content of the isolates ranged from $39.0 \%$ to $47.3 \%$ (Table 2). Particularly noteworthy was the finding that the G+C contents of NGRI 0101, 0315, 0404, 0524 and 0529 were all around $45 \mathrm{~mol} \%$, which is consistent with those of L. plantarum, whereas strains NGRI 0304 and 0305 showed lower $\mathrm{G}+\mathrm{C}$ contents (less than 40\%).

DNA relatedness was analyzed using the isolated strains along with the 6 type strains, L. casei JCM $1134^{\mathrm{T}}$, L. plantarum JCM $1149^{\mathrm{T}}$, L. rhamnosus JCM $1136^{\mathrm{T}}, L$. pentosus $\mathrm{JCM} 1558^{\mathrm{T}}$, P. acidilactici $\mathrm{JCM} 8797^{\mathrm{T}}$ and $P$. pentosaceus JCM $5890^{\mathrm{T}}$ (Table 3). Levels of DNA relatedness among strains NGRI 0001, 0130 and 0510 and the 5 type strains were lower than $57 \%$. This clearly indicates that these isolates do not belong to the $L$. casei group, L. plantarum group or Pediococcus species, as these values are well below the $70 \%$ threshold for definition of bacterial species (Wayne et al. 1987). Strains NGRI 0101, 0315, 0404, 0524 and 0529 all showed high levels of DNA relatedness (> 70\%) with L. plantarum JCM $1149^{\mathrm{T}}$, while strains NGRI 0110 and 0225 showed more than $80 \%$ DNA relatedness to L. rhamnosus JCM $1136^{\mathrm{T}}$ and L. pentosus JCM $1558^{\mathrm{T}}$.

The experimental results summarized above confirmed L. plantarum NGRI 0101, L. rhamnosus NGRI 0110, $L$. pentosus NGRI 0225, $P$. pentosaceus NGRI 0304, $P$. pentosaceus NGRI 0305, L. plantarum NGRI 0315, L. plantarum NGRI 0404, L. plantarum NGRI 0524 and L. plantarum NGRI 0529. However, because strains NGRI 0001, NGRI 0130 and NGRI 0510 showed significant similarities to the reference strains used, it seemed best to analyze the complete nucleotide sequences of their 16S rRNA gene.

\section{Phylogenetic analysis of the complete 16S rRNA gene sequence}

The complete nucleotide sequences of the 16S rRNA coding genes were determined for two isolated strains,
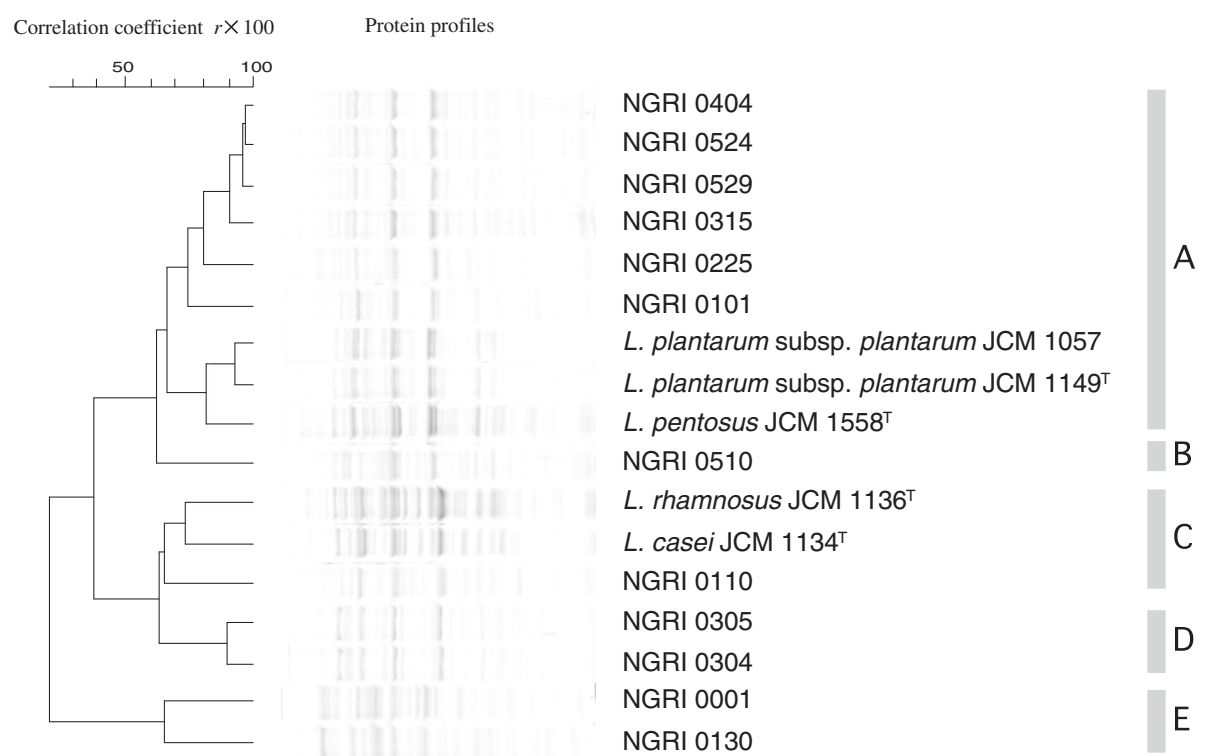

Figure 5 Protein profiles of representative LAB isolates and reference strains. The left-hand side of the figure shows the mean correlation coefficients expressed as percentages $(r \times 100)$ and represented as a dendrogram calculated through UPGMA analysis of the selected strains. The right-hand side of the figure shows the delineation of the 5 clusters. 
Table 3 Levels of DNA-DNA homology for isolated strains

\begin{tabular}{|c|c|c|c|c|c|c|c|c|c|c|c|c|c|c|c|c|c|c|}
\hline \multirow[b]{2}{*}{ Strain } & \multicolumn{18}{|c|}{ DNA-DNA reassociation $\%$ with } \\
\hline & $\begin{array}{l}\text { NGRI } \\
0001\end{array}$ & $\begin{array}{l}\text { NGRI } \\
0101\end{array}$ & $\begin{array}{l}\text { NGRI } \\
0110\end{array}$ & $\begin{array}{l}\text { NGRI } \\
0130\end{array}$ & $\begin{array}{l}\text { NGRI } \\
0225\end{array}$ & $\begin{array}{l}\text { NGRI } \\
0304\end{array}$ & $\begin{array}{l}\text { NGRI } \\
0305\end{array}$ & $\begin{array}{l}\text { NGRI } \\
0315\end{array}$ & $\begin{array}{l}\text { NGRI } \\
0404\end{array}$ & $\begin{array}{l}\text { NGRI } \\
0510\end{array}$ & $\begin{array}{l}\text { NGRI } \\
0524\end{array}$ & $\begin{array}{l}\text { NGRI } \\
0529\end{array}$ & $\begin{array}{l}\mathrm{JCM} \\
1134^{\top}\end{array}$ & $\begin{array}{l}\text { JCM } \\
1136^{\top}\end{array}$ & $\begin{array}{l}\text { JCM } \\
1149^{\top}\end{array}$ & $\begin{array}{l}\text { JCM } \\
1558^{\top}\end{array}$ & $\begin{array}{l}\mathrm{JCM} \\
5885^{\top}\end{array}$ & $\begin{array}{l}\text { JCM } \\
5890^{\top}\end{array}$ \\
\hline $\begin{array}{l}\text { L. casei JCM } \\
1134^{\top}\end{array}$ & 30.2 & 34.1 & 45.3 & 40.1 & 20.3 & 21.9 & 19.8 & 25.1 & 18.2 & 10.9 & 25.2 & 36.2 & 100 & - & - & - & - & - \\
\hline $\begin{array}{l}\text { L. rhamnosus } \\
\text { JCM } 1136^{\top}\end{array}$ & 28.6 & 26.4 & 89.3 & 36.2 & 21.3 & 14.2 & 26.7 & 12.4 & 21.5 & 56.3 & 42.3 & 31.2 & - & 100 & - & - & - & - \\
\hline $\begin{array}{l}\text { L. plantarum } \\
\text { JCM } 1149^{\top}\end{array}$ & 32.3 & 83.9 & 10.2 & 15.3 & 25.6 & 18.9 & 21.5 & 90.1 & 82.3 & 12.9 & 79.2 & 84.3 & - & - & 100 & - & - & - \\
\hline $\begin{array}{l}\text { L. pentosus } \\
\text { JCM } 1558^{\top}\end{array}$ & 28.3 & 30.2 & 11.2 & 19.3 & 82.9 & 34.2 & 45.6 & 42.3 & 35.2 & 26.3 & 39.1 & 36.8 & - & - & - & 100 & - & - \\
\hline $\begin{array}{l}P . \\
\text { pentosaceus } \\
\text { JCM } 5890^{\top}\end{array}$ & 10.8 & 12.8 & 17.6 & 20.3 & 21.6 & 83.1 & 87.1 & 18.1 & 16.2 & 17.3 & 15.9 & 14.3 & - & - & - & - & 100 & - \\
\hline $\begin{array}{l}\text { P. acidilactici } \\
\text { JCM } 8797^{\top}\end{array}$ & 15.6 & 14.9 & 17.1 & 20.5 & 12.3 & 16.5 & 23.1 & 13.7 & 18.7 & 19.3 & 18.1 & 23.8 & - & - & - & - & - & 100 \\
\hline
\end{tabular}

- Not tested.

Identities over $70 \%$ were indicated by boldface.

NGRI 0001 and NGRI 0130, which were not identified in the experiments summarized above. The full $16 \mathrm{~S}$ rDNA sequences of the isolates have been deposited in the DDBJ under accession numbers AB362983 and AB362987. Blast analysis revealed that the $16 \mathrm{~S}$ rRNA gene sequence of strain NGRI 0001 showed similarity with those of $L$. buchneri CD034 (CP003043) (98.64\%), L. buchneri NRRL B-30929 (CP002652) (98.57\%) and L. buchneri JCM $1115^{\mathrm{T}}$ (NR_041293) (98.54\%), while the sequence of strain NGRI 0130 showed similarity to those of $L$. rapi YIT $11204^{\mathrm{T}}$ (NR_041659) (98.9\%), L. rapi YIT 11688 (AB366399) (98.9\%) and L. buchneri CD034 (97.5\%) (Figure 6). From these results, strains NGRI 0001 and NGRI 0130 were identified as L. buchneri and L. rapi, respectively.

\section{Discussion}

In tropical and subtropical regions, the ensiling process often yields only poor quality silage. Two of the reasons are butyric fermentation by butyric acid bacteria and consumption of the nutrients in the silage by coliform bacteria (Tanaka et al. 1994). Butyric acid is usually produced at high temperatures $\left(30-50^{\circ} \mathrm{C}\right)$ by butyric acid bacteria, which have the ability to grow under those conditions. Therefore, to prevent proliferation of butyric acid bacteria and coliform bacteria, silage-making LAB must be capable of rapid growth and high production of lactic acid at high temperatures. Much effort has gone into improving the quality of silage (Weinberg et al. 2007; Lindsey and Kung Jr. 2010; Parvin et al. 2010). In those studies, LABs grown at room temperature showed great ability to improve the quality of silage. However, it was unclear whether strains showing high lactic acid production could grow ahead of butyric acid bacteria or coliform bacteria at higher temperatures $\left(>37^{\circ} \mathrm{C}\right)$, which will be necessary for potentially useful candidates to adapt to tropical and subtropical regions. To prepare potential inoculants for ensilage at high temperature, we isolated LABs from silage prepared in southwestern Japan, where the weather can be hot and humid.

The 12 strains of silage-making LABs tested showed distinct phenotypes that were irreconcilable with the reference strains, which included the type strains of $L$. plantarum, $L$. pentosus, $L$. casei and L. rhamonsus, 5 strains frequently used in silage preparation and frequently isolated from silage (Filya et al. 2000; Nishino et al. 2004; Okine et al. 2005; Klocke et al. 2006). It was difficult to distinguish between $L$. plantarum and its related species, $L$. pentosus, and between $L$. casei and $L$. rhamonsus. Although we applied phage typing to these closely related LAB strains (Doi et al. 2003), we were unable to do a complete identification. We therefore attempted to identify the isolated LABs by comparing the sequences of the 16S-23S rRNA ITS and the $16 \mathrm{~S}$ rRNA V2-V3 region. Both approaches enabled identification of several clusters, including the L. plantarum and $L$. casei groups, among others (Figure 2). Although strain NGRI 0110 was distributed to the $L$. casei group, it was impossible to distinguish among $L$. casei, $L$. paracase $i$ and L. rhamonsus. Strains NGRI 0304 and 0305, which were grouped with $P$. pentosaceus based on their ITS sequences, were categorized to the $L$. plantarum group based on their $\mathrm{V} 2-\mathrm{V} 3$ region sequences. These results indicate that although we were able to classify the isolated LABs at the genus level, we could not resolve them at the species level.

RAPD-PCR profiles obtained using primers AP-A-2 and AP-A-23 enabled us to distinguish among closely related silage-making LABs when $L$. casei, L. rhamonsus, $L$. plantarum and $L$. pentosus were used as references. The RAPD-PCR patterns of L. plantarum (lanes 13 and 15 in Figure 3) obtained with primer AP-A-23 were 


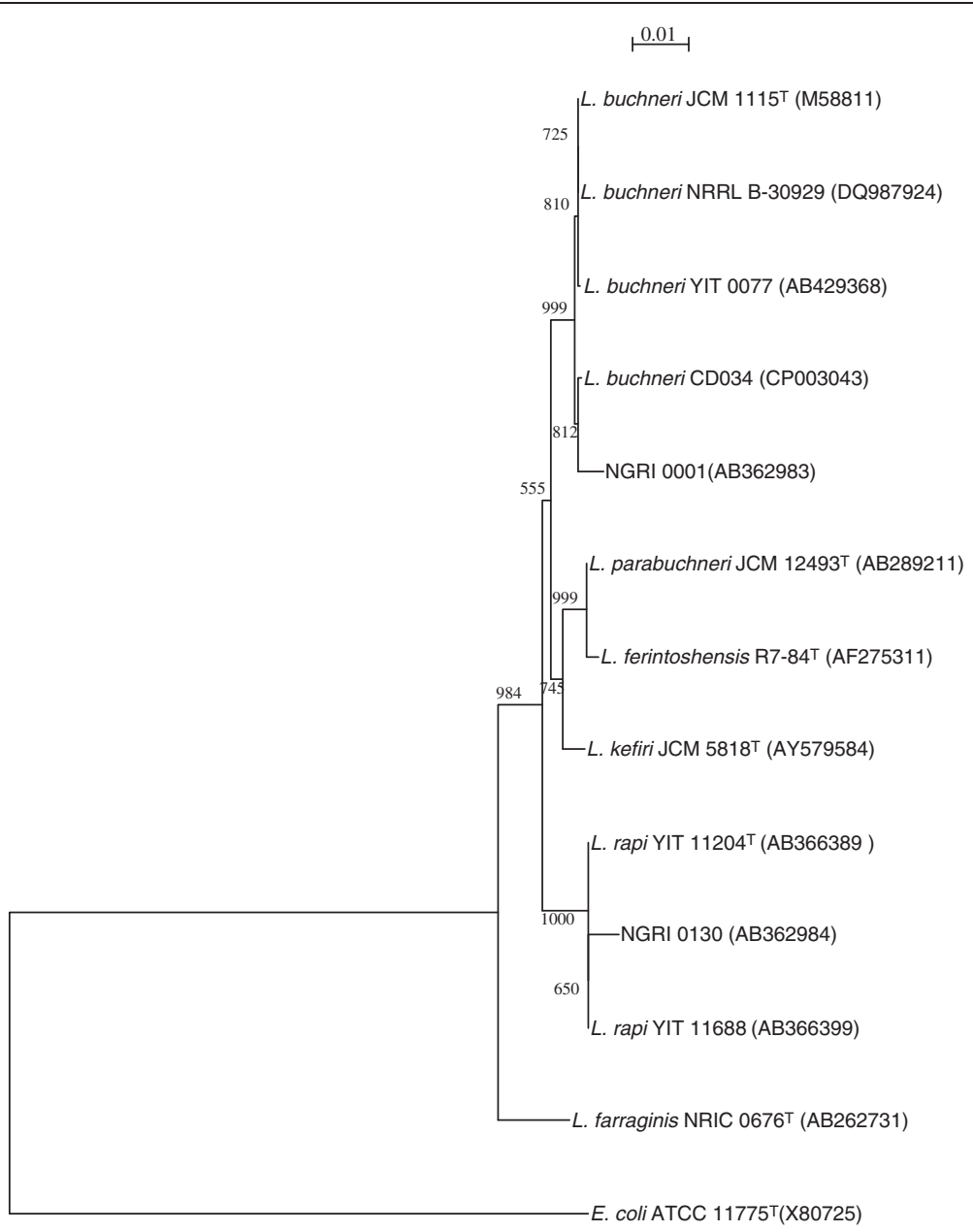

Figure 6 Phylogenetic trees constructed using the neighbor-joining method with the full-length16S rRNA gene sequences from the isolated LAB strains and their taxonomic neighbors. The gene sequence of 16S rRNA from E. coli ATCC 11775 (X80725) was used as the outgroup. Bootstrap values based upon 1000 replicates are included at the major branch points. The bars show the number of nucleotide substitutions per site.

identical, and the patterns in lanes $2,8,9,11$ and 12 were identified as L. plantarum. These primers thus show a potential for L. plantarum-specific typing, along with those reported previously (Johansson et al. 1995; Quere et al. 1997). With the 25 primers used in this study, however, we were unable to resolve profiles specific for $L$. rhamnosus or L. pentosus.

There have been few studies involving the immunoidentification of bacteria using monoclonal antibodies, and those that have been done focused mainly on pathogenic bacteria (Hearty et al. 2006; Klesius et al. 2006). With respect to LABs, only immuno-identification of $L$. casei strain Shirota in the gastrointestinal tract has been reported (Yuki et al. 1999). In the present study, an anti- $L$. plantarum monoclonal antibody reacted positively with species belonging to L. plantarum (NGRI 0101, 0315, 0404, 0524, 0529 and JCM 1149 ${ }^{\mathrm{T}}$ ) and L. pentosus (NGRI 0225 and JCM 1558 ${ }^{\mathrm{T}}$ ) (Figure 4(A)). According to the manufacturer, this antibody reacts positively with only L. plantarum among 25 strains of LAB, 2 strains of yeast and 5 other microorganisms; however, its reactivity with $L$. pentosus has never been tested. From the above results, we suggest this antibody could be used to identify $L$. plantarum and L. pentosus, and that it is impossible to differentiate between those two closely related species. The cell surfaces of $L$. plantarum and L. pentosus, which both contain meso-diaminopimelic acid in their peptidoglycan, likely have similar structures and antigens. On the other hand, the anti-L. casei monoclonal antibody tested could distinguish between L. casei JCM $1134^{\mathrm{T}}$ and $L$. rhamnosus JCM $1136^{\mathrm{T}}$. Strain NGRI 0110, which should be identified as L. rhamnosus, reacted slightly to this antibody. Differences in the immuno-reactions among the isolates and reference strains were also observed in clustering constructed based on the cell protein profiles (Figure 5). Such variation among $L$. casei and $L$. rhamnosus strains 
could be caused by cell surface reactions similar to those mediating adhesion to intestinal mucus membranes (Ouwehand et al. 1999).

Dendrograms obtained using SDS-PAGE with whole-cell protein extracts from $\mathrm{LAB}$ isolates and reference strains have been applied for rapid differentiation of species from fermented sausages, bread, yoghurt, cheese, plants and human faecal samples (Dimitrov et al. 2005; Ricciardi et al. 2005; Benito et al. 2008). When we applied this method to differentiation of silage-making $\mathrm{LAB}$, we found good agreement between the SDS-PAGE profiles and the physiological and genetic characteristics of the LAB tested. There appeared to be obvious differentiation among the L. plantarum group (cluster A), L. casei group (cluster C) and $P$. pentosaceus group (cluster D), and strains NGRI 0001, 0130 and 0510 were separated into the known groups. Moreover, since strain NGRI 0510 was identified as P lolii, a novel Pediococcus species (Doi et al. 2009; Doi et al. 2013), its phylogenetic position may be specific.

From the results of phylogenetic analysis using the complete 16S rRNA sequences, strains NGRI 0001 and 0130 were identified as $L$. buchneri and $L$. rapi, respectively (Figure 6). Because L. buchneri, L. kefiri, L. parabuchneri and $L$. rapi are phylogenetically the most closely related species (Watanabe et al. 2009), this result is consistent with the finding that the partial sequence of the 16S rRNA from strain NGRI 0001 was similar with that from $L$. buchneri and L. kefiri (Figure 2A).

In conclusion, our results show that representative strains isolated from silage produced in hot and humid weather contain six strains belonging to L. plantarum (NGRI 0101, 0315, 0404, 0524 and 0529), L. pentosus (NGRI 0225), L. rhamonsus (NGRI 0110), L. buchneri (NGRI 0001), L. rapi (NGRI 0130) P. pentosaceus (NGRI 0304 and 0305) and P. lolii (NGRI 0510). Although strain NGRI 0315 was identified as L. plantarum, its growth rate was slower than those of other L. plantarum strains (Figure 1). Such slow growing strains exhibit greater acid tolerance than rapidly growing strains (data not shown). It therefore seems likely that rapidly growing LABs would produce lactic acid to reduce $\mathrm{pH}$ in silage, after which large numbers of cells from acid-tolerant strains living at low $\mathrm{pH}$ could competitively inhibit the growth of spoilage microbes, thereby contributing to silage stability. We will report on the application and evaluation of these strains as silage starters adapted to hot and humid weather.

\section{Competing interests}

The authors declare that they have no competing interests.

\section{Authors' contributions}

The work presented here was carried out in collaboration between all authors. KD, SO (Sadahiro Ohmomo) and SO (Seiya Ogata) defined the research theme. KD, YN and HK designed methods and experiments, carried out the laboratory experiments, analyzed the data, interpreted the results and wrote the paper. KM co-designed the SDS-PAGE profiling experiments, and co-worked on associated data collection and their interpretation. YF co-designed experiments, discussed analyses, interpretation, and presentation. All authors have contributed to, seen and approved the manuscript.

\section{Acknowledgements}

This work was supported in part by Grants-in-Aid for Scientific research (A, No. 07556094) from the Ministry of Education, Culture, Sports, Science and Technology of Japan, the Research Foundation of the Ministry of Agriculture, Forestry and Fisheries of Japan, and the Japan Ecology Foundation.

\section{Author details}

${ }^{1}$ Microbial Genetic Division, Institute of Genetic Resources, Faculty of Agriculture, Kyushu University, 6-10-1 Hakozaki, Higashi-ku, Fukuoka 812-8581, Japan. ${ }^{2}$ Faculty of Arts and Science, Kyushu University, 744 Motooka, Nishi-ku, Fukuoka 819-0395, Japan. ${ }^{3}$ Microbe Division, Japan Collection of Microorganisms, RIKEN BioResource Center, 3-1-1 Koyadai, Tsukuba, Ibaraki 305-0074, Japan. ${ }^{4}$ Asama chemical Co., Ltd., 20-3 Nihonbashi-Kodenma-cho, Chuo-ku, Tokyo 103-0001, Japan.

Received: 22 June 2013 Accepted: 2 September 2013

Published: 25 September 2013

\section{References}

Adnan S, Li N, Miura H, Hashimoto Y, Yamamoto H, Ezaki T (1993) Covalently immobilized DNA plate for luminometric DNA-DNA hybridization to identify viridans streptococci in under 2 hours. FEMS Microbiol Lett 106:139-142

Benito MJ, Serradilla MJ, Ruiz-Moyano S, Martín A, Pérez-Nevado F, Córdoba MG (2008) Rapid differentiation of lactic acid bacteria from autochthonous fermentation of Iberian dry-fermented sausages. Meat Sci 80:656-661

Cai Y, Benno Y, Ogawa M, Kumai S (1999) Effect of applying lactic acid bacteria isolated from forage crops on fermentation characteristics and aerobic deterioration of silage. J Dairy Sci 82:520-526

Curk MC, Hubert JC, Bringel F (1996) Lactobacillus paraplantarum sp. nov., a new species related to Lactobacillus plantarum. Int J Syst Bacteriol 46:595-598

Dimitrov Z, Michaylova M, Mincova S (2005) Characterization of Lactobacillus helveticus strains isolated from Bulgarian yoghurt, cheese, plants and human faecal samples by sodium dodecilsulfate polyacrylamide gel electrophoresis of cell-wall proteins, ribotyping and pulsed field gel fingerprinting. Int Dairy J 15:998-1005

Doi K, Zhang Y, Nishizaki Y, Umeda A, Ohmomo S, Ogata S (2003) A comparative study and phage typing of silage-making Lactobacillus bacteriophages. J Biosci Bioeng 95:518-525

Doi K, Nishizaki Y, Fujino Y, Ohshima T, Ohmomo S, Ogata S (2009) Pediococcus Iolii sp. nov., isolated from ryegrass silage. Int J Syst Evol Microbiol 59:1007-1010

Doi K, Mori K, Tashiro K, Fujino Y, Nagayoshi Y, Hayashi Y, Kuhara S, Ohshima T (2013) Draft Genome Sequence of Pediococcus Iolii NGRI 0510Q ${ }^{\top}$ isolated from ryegrass silage. GenomeA 1:e00156-12

Ennahar S, Cai Y, Fujita Y (2003) Phylogenetic diversity of lactic acid bacteria associated with paddy rice silage as determined by $16 \mathrm{~S}$ ribosomal DNA analysis. Appl Environ Microb 69:444-451

Ezaki T, Hashimoto Y, Yabuuchi E (1989) Fluorometric deoxyribonucleic acid-deoxyribonucleic acid hybridization in microdilution wells as an alternative to membrane filter hybridization in which radioisotopes are used to determine genetic relatedness among bacterial strains. Int J Syst Bacteriol 39:224-229

Filya I, Ashbell G, Hen Y, Weinberg ZG (2000) The effect of bacterial inoculants on the fermentation and aerobic stability of whole crop wheat silage. Anim Feed Sci Tech 88:39-46

Fujino Y, Kawatsu R, Inagaki F, Umeda A, Yokoyama T, Okaue Y, Iwai S, Ogata S, Ohshima T, Doi K (2008) Thermus thermophilus TMY isolated from silica scale taken from a geothermal power plant. J Appl Microbiol 104:70-78

Giraffa G, Chanishvili N, Widyastuti Y (2010) Importance of lactobacilli in food and feed biotechnology. Res Microbiol 161(6):480-487

Hammes WP, Hertel C (2006) The genera Lactobacillus and Carnobacterium. In: Dworkin M, Falkow S, Rosenberg E, Schleiferand K-H, Stackebrandt E (ed) The Prokaryotes, 3rd edition. Springer-Verlag, New-York, pp 320-403

Hearty S, Leonard P, Quinn J, O'Kennedy R (2006) Production, characterisation and potential application of a novel monoclonal antibody for rapid identification of virulent Listeria monocytogenes. J Microbiol Meth 66:294-312 
Holzer M, Mayrhuber E, Danner H, Braun R (2003) The role of Lactobacillus buchneri in forage preservation. Trends Biotechnol 21:282-287

Huang CH, Lee FL, Liou JS (2010) Rapid discrimination and classification of the Lactobacillus plantarum group based on a partial dnaK sequence and DNA fingerprinting techniques. Antonie Van Leeuwenhoek 97:289-296

Johansson ML, Quednau M, Molin G, Ahrné S (1995) Randomly amplified polymorphic DNA (RAPD) for rapid typing of Lactobacillus plantarum. Lett Appl Microbiol 21:155-159

Kaneshige N, Zong Y, Nishiyama K, Doi K, Tanaka O, Ohmomo S, Ogata S (1994) Relationship between the quality of Italian ryegrass silage and the presence of phages for silage-making lactobacilli. Nippon Nogeik Kaishi (in Japanese) 68:1219-1221

Klesius P, Evans J, Shoemaker C, Yeh H, Goodwin AE, Adams A, Thompson K (2006) Rapid detection and identification of Streptococcus iniae using a monoclonal antibody-based indirect fluorescent antibody technique. Aquaculture 258:180-186

Klocke M, Mundt K, Idler C, McEniry J, O'Kiely P, Barth S (2006) Monitoring Lactobacillus plantarum in grass silages with the aid of 165 rDNA-based quantitative real-time PCR assays. Syst Appl Microbiol 29:49-58

Kojima S, Takizawa S, Tamura S, Fujinaga S, Benno Y, Nakase T (1993) A new medium for the isolation of lactobacilli from kefir grains. Biosci Biotech Bioch $57: 119-120$

Laemmli (1970) Cleavage of structural proteins during the assembly of the head of bacteriophage T4. Nature 227:680-685

Lindsey JR, Kung L, Jr (2010) Effects of combining Lactobacillus buchneri 40788 with various lactic acid bacteria on the fermentation and aerobic stability of corn silage. Anim Feed Sci Tech 159:105-109

Mulrooney CN, Kung L, Jr (2008) The effect of water temperature on the viability of silage inoculants. J Dairy Sci 91:236-240

Namihira T, Shinzato N, Akamine H, Maekawa H, Matsui T (2010) Influence of nitrogen fertilization on tropical-grass silage assessed by ensiling process monitoring using chemical and microbial community analyses. J App Microbiol 108:1954-1965

Nishino N, Wada H, Yoshida M, Shiota H (2004) Microbial counts, fermentation products, and aerobic stability of whole crop corn and a total mixed ration ensiled with and without inoculation of Lactobacillus casei or Lactobacillus buchneri. J Dairy Sci 87:2563-2570

Ohmomo S, Tanaka O, Kitamoto HK, Cai Y (2002) Silage and microbial performance, old story but new problems. JARQ 36:59-71

Okine A, Hanada M, Aibibula Y, Okamoto M (2005) Ensiling of potato pulp with or without bacterial inoculants and its effect on fermentation quality, nutrient composition and nutritive value. Anim Feed Sci Tech 121:329-343

Ouoba LI, Nyanga-Koumou CA, Parkouda C, Sawadogo H, Kobawila SC, Keleke S, Diawara B, Louembe D, Sutherland JP (2010) Genotypic diversity of lactic acid bacteria isolated from African traditional alkaline-fermented foods. J Appl Microbiol 108:2019-2029

Ouwehand AC, Kirjavainen PV, Grönlund M-M, Isolauri E, Salminen SJ (1999) Adhesion of probiotic micro-organisms to intestinal mucus. Int Dairy J 9:623-630

Parvin S, Wang C, Li Y, Nishino N (2010) Effects of inoculation with lactic acid bacteria on the bacterial communities of Italian ryegrass, whole crop maize, guinea grass and rhodes grass silages. Anim Feed Sci Tech 160:160-166

Quere F, Deschamps A, Urdaci MC (1997) DNA probe and PCR-specific reaction for Lactobacillus plantarum. J Appl Microbiol 82:783-790

Ricciardi A, Parente E, Piraino P, Paraggio M, Romano P (2005) Phenotypic characterization of lactic acid bacteria from sourdoughs for Altamura bread produced in Apulia (Southern Italy). Int J Food Microbiol 98:63-72

Tanaka O, Kimura H, Takahashi E, Ogata S, Ohmomo S (1994) Screening of lactic acid bacteria for silage inoculants by using a model system of silage fermentation. Biosci Biotech Bioch 58:1412-1415

Tannock GW, Tilsala-Timisjarvi A, Rodtong S, NG J, Munro K, Alatossava T (1999) Identification of Lactobacillus isolates from the gastrointestinal tract, silage, and yoghurt by 165 -23S rRNA gene intergenic spacer region sequence comparisons. Appl Environ Microb 65:4264-4267

Torriani S, Felis GE, Dellaglio F (2001) Differentiation of Lactobacillus plantarum, $L$. pentosus, and L. paraplantarum by recA gene sequence analysis and multiplex PCR assay with recA gene-derived primers. Appl Environ Microbiol 67:3450-3454

Watanabe K, Fujimoto J, Tomii Y, Sasamoto M, Makino H, Kudo Y, Okada S (2009) Lactobacillus kisonensis sp. nov., Lactobacillus otakiensis sp. nov., Lactobacillus rapi sp. nov. and Lactobacillus sunkii sp. nov., heterofermentative species isolated from sunki, a traditional Japanese pickle. Int J Syst Evol Microbiol 59:754-760

Wayne LG, Brenner DJ, Colwell RR, Grimont PAD, Kandler O, Krichevsky MI, Moore LH, Moore WEC, Murray RGE, Stackebrandt E, Starr MP, Truper HG (1987) International committee on systematics bacteriology. Report of the ad hoc committee on reconciliation of approaches to bacterial systematics. Int J Syst Microbiol 37:463-464

Weinberg ZG, Shatz O, Chen Y, Yosef E, Nikbahat M, Ben-Ghedalia D, Miron $J$ (2007) Effect of lactic acid bacteria inoculants on in vitro digestibility of wheat and cornsilages. J Dairy Sci 90:4754-4762

Yan PM, Xuea WT, Tan SS, Zhang H, Chang XH (2008) Effect of inoculating lactic acid bacteria starter cultures on the nitrite concentration of fermenting Chinese paocai. Food Control 19:50-55

Yuki N, Watanabe K, Mike A, Tagami Y, Tanaka R, Ohwaki M, Morotomi M (1999) Survival of a probiotic, Lactobacillus casei strain Shirota, in the gastrointestinal tract: selective isolation from faeces and identification using monoclonal antibodies. Int J Food Microbiol 48:51-57

doi:10.1186/2193-1801-2-485

Cite this article as: Doi et al:: Identification of thermo tolerant lactic acid bacteria isolated from silage prepared in the hot and humid climate of Southwestern Japan. SpringerPlus 2013 2:485.

\section{Submit your manuscript to a SpringerOpen ${ }^{\circ}$ journal and benefit from:}

- Convenient online submission

- Rigorous peer review

- Immediate publication on acceptance

- Open access: articles freely available online

- High visibility within the field

- Retaining the copyright to your article

Submit your next manuscript at $>$ springeropen.com 